\title{
LOWER PALAEOZOIC STRATIGRAPHY AROUND DANMARK FJORD, EASTERN NORTH GREENLAND
}

\author{
John S. Peel, J. R. Ineson, P. D. Lane and H. A. Armstrong
}

Geological fieldwork in the Caledonian foreland of eastern North Greenland commenced during 1979 (Peel, 1980) was continued in 1980 with systematic regional mapping on a 1:100 000 photomosaic base of western Kronprins Christian Land, from Centrum Sø in the south to Prins Frederik Øer in the north (fig. 6). Mapping was concentrated on the essentially autochthonous sequence adjacent to Danmark Fjord, with Hurst \& McKerrow (this report) investigating the Caledonian Nappe sequence further to the east (Map 1). In addition to activities in Kronprins Christian Land, short visits were also made to Kap Holbæk and Valdemar Glückstadt Land, on the western side of Danmark Fjord.

\section{Kronprins Christian Land}

After the first reconnaissance visit, Peel (1980) reviewed geological and nomenclative problems associated with the Lower Palaeozoic carbonate stratigraphy of Kronprins Christian Land from the time of the first introduction of the embracive term Centrum Limestone by Adams $\&$ Cowie (1953) to the latest revision of this work by Scrutton (1975). Peel recognised several formations described from Peary Land to the north-west (Troelsen, 1949; Christie \& Peel, 1977) within the Centrum Limestone, but the scope of the 1979 fieldwork in Kronprins Christian Land was too restricted to permit a more conclusive evaluation of the stratigraphy. In 1980, key localities of Adams \& Cowie (1953) were revisited, making stratigraphic revision possible.

Employment of the terms Centrum Limestone and Centrum Formation in the varied usages and definitions of Adams \& Cowie (1953), Cowie (1961, 1971) and Scrutton (1975) is discontinued. The general ambiguity and lack of precision surrounding the terms can only be compounded by further modification in their usage. Most of the Ordovician strata in Kronprins Christian Land can be readily assigned to the Wandel Valley Formation and Børglum River Formation, originally described by Troelsen (1949) from Peary Land, making a dual system of nomenclature unnecessary. In addition, widespread stratigraphic repetition throughout Kronprins Christian Land due to thrusting, not recognised by Adams \& Cowie (1953), makes the concept of a $2 \mathrm{~km}$ thick Centrum Formation (sensu Scrutton, 1975) untenable.

The Danmarks Fjord Dolomite of Fränkl (1955) and the Amdrup Formation of Cowie (1971) are recognised but, as discussed below, their status is reduced to that of members within the Wandel Valley Formation (fig. 7). A new, as yet un-named formation between the Wandel Valey Formation and the Børglum River Formation is in part equivalent to the informally named Opikina Limestone of Scrutton (1975). The un-named Silurian (?) dolomite formation and un-named Silurian limestone formation of Christie \& Peel (1977) are both present in Kronprins Christian Land (Peel, 1980), although not recognisable in the 


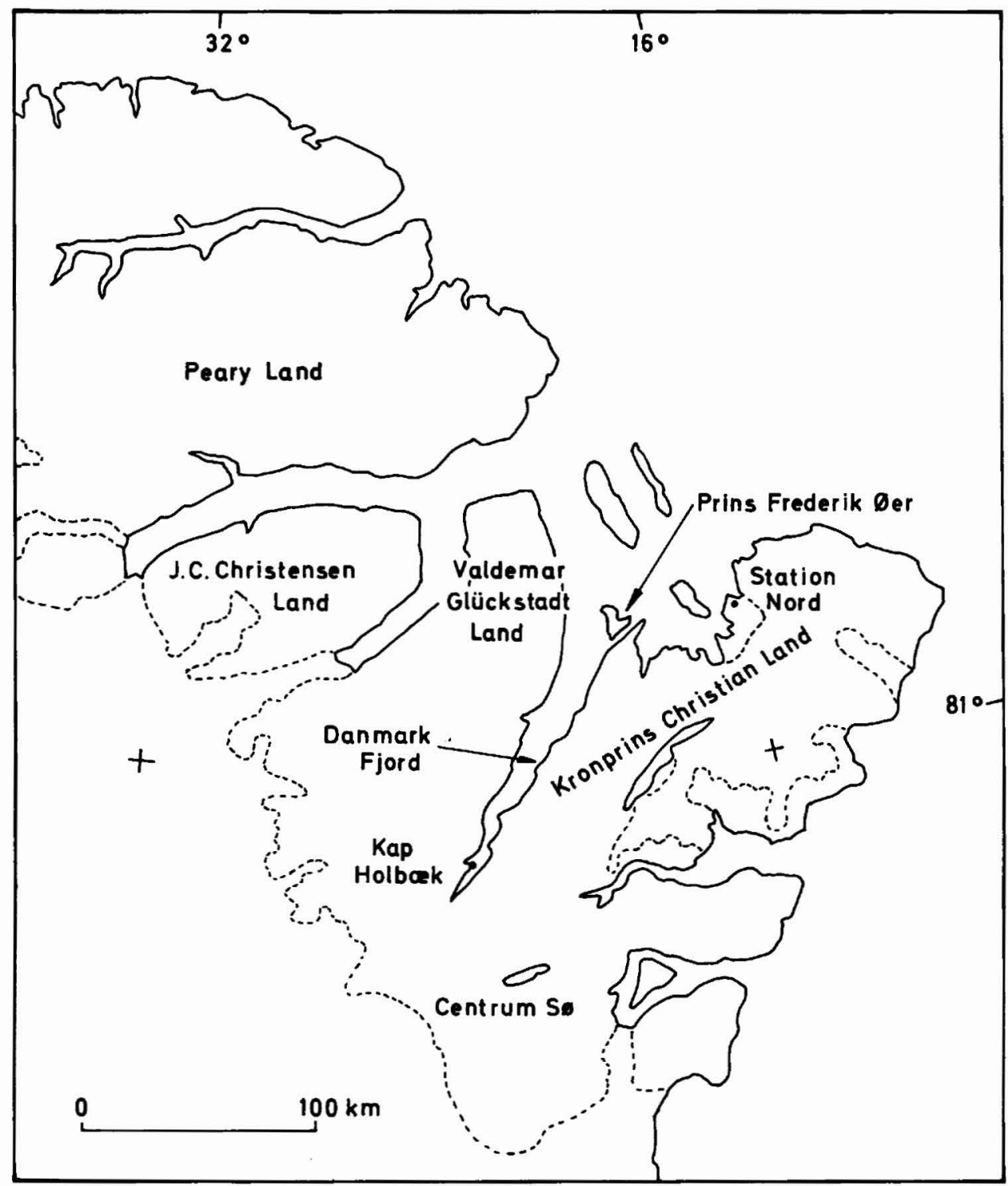

Fig. 6. Geographical localities in north-eastern Greenland.

stratigraphic scheme of Scrutton (1975). It is anticipated that these formations will be formally named in Peary Land. The Drømmebjerg Formation of Fränkl (1955) and Scrutton (1975) consists of a series of individual carbonate mounds, the Silurian reefs of Peel (1980). The formation name can be maintained, also to include similar mounds in Peary Land (Christie \& Peel, 1977; Mabillard, 1980). 
Fig. 7. Lower Palaeozoic stratigraphy of western Kronprins Christian Land and northern Valdemar Glückstadt Land.

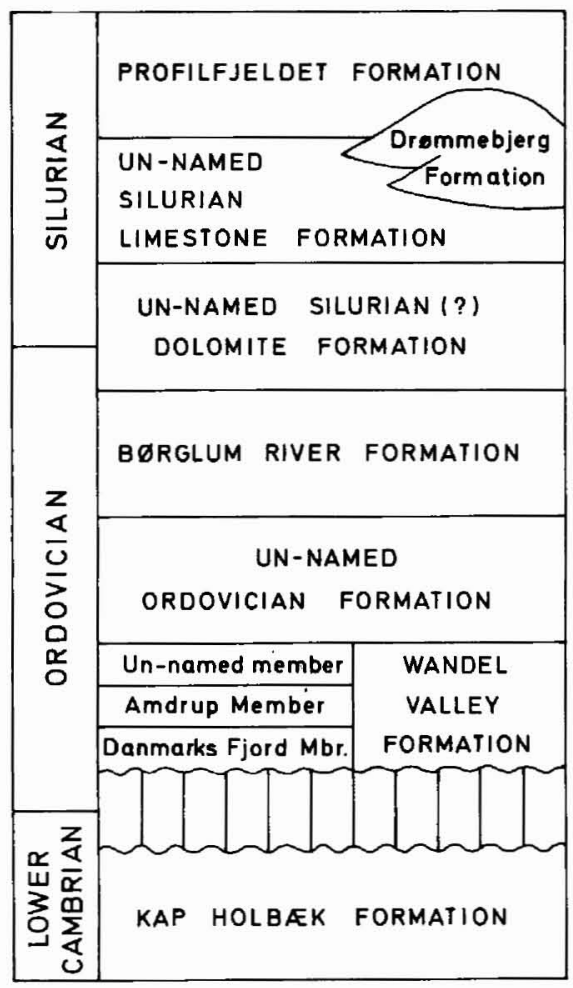

In Peary Land, the Silurian carbonates are overlain by an un-named black shale formation and an un-named flysch formation (Christie \& Peel, 1977). While shales occur at the base of the clastic sequence in westernmost outcrops in Kronprins Christian Land, they appear to be generally absent in more easterly outcrops (Peel, 1980; J. M. Hurst and W. S. McKerrow, personal communication). In consequence, the Profilfjeldet Shales of Fränkl (1955) are maintained as a formation in Kronprins Christian Land, equivalent to the as yet un-named Silurian black shale and flysch formations, as suggested by Peel (1980).

Significant new stratigraphic information obtained from western Kronprins Christian Land during 1980 is centred upon the resolution of the former Centrum Limestone problem discussed above, with the establishment of the new, as yet un-named, Ordovician formation between the Wandel Valley Formation and the Børglum River Formation, and the recognition that Silurian carbonate mounds of the Drømmebjerg Formation may occur at different levels within the un-named Silurian limestone formation. The new Ordovician formation is about $100 \mathrm{~m}$ thick, with a lower dark dolomite unit overlain by recessive, pale weathering dolomite. Peel (1980, p. 68) commented that a particularly large carbonate mound ('Silurian reef') occurs to the north-west of locality $D$ in his fig. 33 . It is this mound complex in particular which is now considered to occur stratigraphically much lower in the un-named Silurian limestone formation than the carbonate mounds in Peary Land. 


\section{Kap Holbak}

Kap Holbæk (fig. 6) was visited briefly by Ineson and Peel in order to examine the Kap Holbæk Formation, the so-called Danmarks Fjord Dolomite and the Amdrup Formation, at localities visited by Adams \& Cowie (1953).

Yellowish weathering sandstones and green siltstones of the Kap Holbæk Formation, considered equivalent to the lower part of the Buen Formation (early Cambrian age) of Peary Land, were found to be cut by small faults which did not penetrate the overlying carbonates. Similar faults were also observed in the cliffs on the opposite side of Danmark Fjord and demonstrate further the presence of a major regional unconformity in north-eastern Greenland beneath carbonates of late Canadian (late Early Ordovician) age (Peel, 1979). In Peary Land, Ordovician carbonates of the Wandel Valley Formation gradually overstep Cambrian clastics and carbonates of the Tavsens Iskappe and Brønlund Fjord Groups (Ineson \& Peel, 1980). At Kap Holbæk, as in northern Valdemar Glückstadt Land (Peel, 1980, fig. 31), the Brønlund Fjord Group has been completely overstepped so that carbonates now assigned to the Wandel Valley Formation rest unconformably on Lower Cambrian clastics of the Kap Holbæk Formation (fig. 8).

Fränkl (1955) gave the name Danmarks Fjord Dolomite to carbonates which occur at Kap Holbæk and at Sæfaxi Elv in Kronprins Christian Land, some $70 \mathrm{~km}$ to the south-east (see Hurst \& McKerrow, this report). Subsequent literature (Cowie, 1961; 1971) has discussed

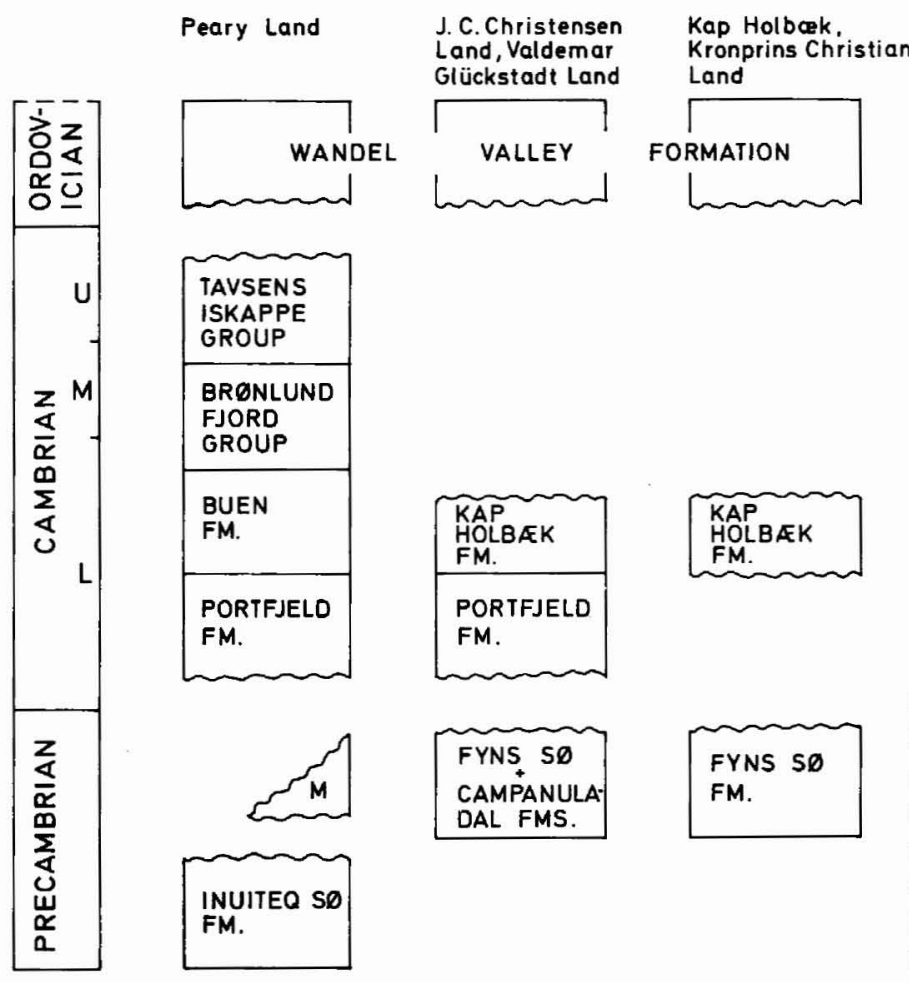

Fig. 8. Cambrian stratigraphy in north-eastern Greenland showing the relationship with underlying Precambrian formations and overstep by the Ordovician Wandel Valley Formation. M, Morænesø Formation. 
the unit as a formation, mainly in terms of its occurrence at Kap Holbæk on the shore of the fjord from which it takes its name (the official name of the fjord has subsequently been established as Danmark Fjord). In consequence, the locality is now considered to be the type locality of the Danmarks Fjord Dolomite, presently regarded as a member within the Wandel Valley Formation.

At Kap Holbæk, the unit consists of 10-12 m of generally brown-weathering dolomite which contrasts with the dark grey weathering, overlying limestones. The contact with the underlying Kap Holbæk Formation is an erosion surface, with the basal $50 \mathrm{~cm}$ consisting of well bedded, sandy and oolitic, cherty dolomite. The upper contact is abrupt and slightly undulating. The general lithology is fine to medium, grey to dark grey, dolomite with undulating laminae or lenticular bedding. White-weathering, lenticular black chert nodules, which in places contain ooliths are common. The laminated horizons often show stromatolites which produce small domes in the lower part of the unit. Beds of intraformational conglomerate and oolite from $5-20 \mathrm{~cm}$ thick occur throughout, and may have erosion surfaces at their base.

The distinct upper surface and the lithological contrast with the overlying dark limestones support the separation of the Danmarks Fjord Dolomite as a distinct stratigraphic entity at Kap Holbæk. However, immediately across Danmark Fjord, some $5 \mathrm{~km}$ to the east, a gradational contact exists between the Danmarks Fjord Dolomite and the overlying limestones of the so-called Amdrup Formation (now considered a member of the Wandel Valley Formation). In consequence, the dolomite is regarded as a member within the Wandel Valley Formation and not a separate formation, as was proposed by Cowie (1971) and Poulsen (1978). The Danmarks Fjord Member, as it is here described, is presumed to be of Early Ordovician age on account of its gradation upwards into late Early Ordovician and younger strata of the Wandel Valley Formation. Fossils are not yet recorded from the Danmarks Fjord Member, although sampling for microfossil search has been undertaken.

It is clear from the present reassessment of the Danmarks Fjord Member that the correlation of this unit with the Early Cambrian Brønlund Fjord Formation (now a part of the Brønlund Fjord Group, see Ineson \& Peel, 1980) suggested by Cowie (1971) is rejected. The tentative correlation of the Danmarks Fjord Member at Kap Holbæk with the Portfjeld Formation of Peary Land as suggested by O'Connor (1979) and discussed by Peel (1979) is quite understandable, since there is considerable lithologic similarity. However, the gradation of the Danmarks Fjord Member into overlying Ordovician limestones at other localities and the correlation of the Kap Holbæk Formation with the Early Cambrian Buen Formation make O'Connor's suggestion untenable.

Poulsen (1978) correlated the Danmark(s) Fjord Dolomite with the upper part of the Portfjeld Formation and the basal Buen Formation, having considered the Kap Holbæk Formation to be equivalent to part of the Portfjeld Formation. The hypothesis seems in part to be based on supposed lithological similarity between the Fyns Sø Formation and the Portfjeld Formation, based on published descriptions. O'Connor (1979) and Clemmensen (1979) comment that the Portfjeld Formation normally overlies the Fyns Sø Formation in J. C. Christensen Land. However, in northern J. C. Christensen Land and eastern Valdemar Glückstadt Land the Portfjeld Formation is reported to rest on the Campanuladal Formation which otherwise underlies the Fyns Sø Formation. Unpublished observations by Hans F. Jepsen and Roger J. Suthren in north-eastern J. C. Christensen Land demonstrate that this overstep by the Portfjeld Formation reflects its deposition on a peneplained surface 
which truncates underlying block-faulted formations, including the Fyns Sø Formation. Thus, the correlation proposed by Poulsen (1978) cannot be accepted and the Fyns Sø Formation is considered to be substantially older than the Early Cambrian Portfjeld Formation. The Portfjeld Formation of Peary Land apparently thins to the south-east and is finally overstepped by the clastics of the Kap Holbæk Formation (equal to the Buen Formation) in the Kap Holbæk area. Current ideas concerning the stratigraphy of the Kap Holbæk area, based on the interaction of sub-Cambrian and sub-Ordovician unconformities, are summarised in fig. 7.

The Amdrup 'Formation' (Cowie, 1971; Scrutton, 1975) at Kap Holbæk consists of a few tens of metres of dark limestones yielding trilobites, ostracodes and gastropods (Adams \& Cowie, 1953). Most of the unit has been eroded, but in Kronprins Christian Land it attains a thickness of about $200 \mathrm{~m}$. The sequence is evidently more marine than the dolomite dominated Wandel Valley Formation of Peary Land (Christie \& Peel, 1977). However, the similarity between the units is sufficient to justify employment of the term Wandel Valley Formation even in the Kap Holbæk - Kronprins Christian Land region, with the Amdrup 'Formation' conveniently being maintained as a member (fig. 7). Pale weathering recessive dolomites which form an un-named upper member of the Wandel Valley Formation in Kronprins Christian Land are lithologically similar to the Peary Land sequence (Christie \& Peel, 1977).

The Kap Holbæk peninsula is cut by a prominent, approximately north-west - south-east fault of at least $500 \mathrm{~m}$ downthrow on the northern side. Thus, the northern part of the peninsula is formed by richly fossiliferous late Ordovician limestones of the Børglum River Formation. Small reversed faults which strike north-east to south-west probably represent the most western compressional faults of the Caledonian Orogeny in north-eastern Greenland.

\section{Valdemar Glückstadt Land}

The Lower Palaeozoic sequence in northern Valdemar Glückstadt Land (fig. 6), originally examined during 1979 (Peel, 1980), was revisited by Lane and Peel and the results of both visits have been combined into a map with scale 1:250 000. Fieldwork in 1980 was concentrated along the eastern shore because of poor exposure in western and central parts.

The recognition of large scale faulting (Map 1) was the most significant addition to the previous season's knowledge, but richly fossiliferous (Lane \& Peel, 1980) carbonate mounds of the Drømmebjerg Formation are more extensive than previously realised. The same stratigraphic scheme as recognised in Kronprins Christian Land is employed, although it is probable that a distinct black shale unit (the un-named Silurian black shale formation of Peary Land) could be recognised at the base of the Profilfjeldet Formation. As in Kronprins Christian Land, the un-named Ordovician formation was mapped as part of the Børglum River Formation. 


\section{References}

Adams, P. J. \& Cowie, J. W. 1953: A geological reconnaissance of the region around the inner part of Danmarks Fjord, Northeast Greenland. Meddr Grønland 111 (7), 24 pp.

Christie, R. L. \& Peel, J. S. 1977: Cambrian-Silurian stratigraphy of Børglum Elv, Peary Land, eastern North Greenland. Rapp. Grønlands geol. Unders. 82, 48 pp.

Clemmensen, L. B. 1979: Notes on the palaeogeographical setting of the Eocambrian tillite-bearing sequence of southern Peary Land, North Greenland. Rapp. Grønlands geol. Unders. 88, 15-22.

Cowie, J. W. 1961: The Lower Palaeozoic geology of Greenland. In Raasch, G. O. (edit.) Geology of the Arctic 1, 160-169. Toronto U.P.

Cowie, J. W. 1971: The Cambrian of the North American Arctic regions. In Holland, C. H. (edit.) Cambrian of the New World, 325-383. London: Interscience.

Fränkl, E. 1955: Weitere Beiträge zur Geologie von Kronprins Christians Land (NE-Grönland). Meddr Grønland 103 (7), 35 pp.

Ineson, J. R. \& Peel, J. S. 1980: Cambrian stratigraphy in Peary Land, eastern North Greenland. Rapp. Grønlands geol. Unders. 99, 33-42.

Lane, P. D. \& Peel, J. S. 1980: Trilobites and gastropods from Silurian carbonate mounds in Valdemar Glückstadt Land, eastern North Greenland. Rapp. Grønlands geol. Unders. 101, 54 only.

Mabillard, J. E. 1980: Silurian carbonate mounds of south-east Peary Land, eastern North Greenland. Rapp. Grønlands geol. Unders. 99, 57-60.

O'Connor, B. 1979: The Portfjeld Formation (? early Cambrian) of eastern North Greenland. Rapp. Grønlands geol. Unders. 88, 23-28.

Peel, J. S. 1979: Cambrian-Middle Ordovician stratigraphy of the Adams Gletscher region, south-west Peary Land, North Greenland. Rapp. Grønlands geol. Unders. 88, 29-39.

Peel, J. S. 1980: Geological reconnaissance in the Caledonian Foreland of eastern North Greenland with comments on the Centrum Limestone. Rapp. Grønlands geol. Unders. 99, 61-72.

Poulsen, V. 1978: The Precambrian-Cambrian boundary in parts of Scandinavia and Greenland. Geol. Mag. 115, 131-136.

Scrutton, C. T. 1975: Corals and stromatoporoids from the Ordovician and Silurian of Kronprins Christian Land, Northeast Greenland. Meddr Grønland 171 (4), 43 pp.

Troelsen, J. C. 1949: Contributions to the geology of the area round Jørgen Brønlunds Fjord, Peary Land, North Greenland. Meddr Grønland 149 (2), 29 pp. 